\title{
Application of a Preliminary Screen to Select Locally Adapted Resistant Rootstock and Soil Amendment for Integrated Management of Tomato Bacterial Wilt in Taiwan
}

Chih-Hung Lin, Department of Plant Pathology, National Chung Hsing University, Taichung, Taiwan 40227, R.O.C. and AVRDC-The World Vegetable Center, Shanhua, Tainan, Taiwan 74199, R.O.C.; Shih-Tien Hsu and Kuo-Ching Tzeng, Department of Plant Pathology, National Chung Hsing University; and Jaw-Fen Wang, AVRDC-The World Vegetable Center

\begin{abstract}
Lin, C.-H., Hsu, S.-T., Tzeng, K.-C., and Wang, J.-F. 2008. Application of a preliminary screen to select locally adapted resistant rootstock and soil amendment for integrated management of tomato bacterial wilt in Taiwan. Plant Dis. 92:909-916.

Host plant resistance and soil amendment (SA) have not been used extensively to manage tomato bacterial wilt caused by Ralstonia solanacearum due to their variable effects over locations. A preliminary screen was developed to increase the chances of identifying successful control measures under diverse conditions. Isolates from three production areas in Taiwan were collected and their virulence evaluated on tomato. Soil samples from four field sites were collected to evaluate ability to suppress the pathogen of SAs consisting of urea or slaked lime alone or combined at $30^{\circ} \mathrm{C}$. The mixture of urea and slaked lime showed the best suppressive effect in three tested soils and was used in subsequent field experiments. Resistant eggplant (EG203) and tomato (Hawaii 7996) rootstocks, selected based on stable resistance against representative strains at the seedling stage, significantly reduced disease incidence in field experiments. EG203 grafted plants exhibited 0 to $2.8 \%$ wilted plants compared with 24.4 to $92.9 \%$ wilted nongrafted plants. Integrated use of Hawaii 7996 as the rootstock and SA provided significantly greater control of wilt than use of Hawaii 7996 as rootstock alone in only one of the four locations, whereas SA did not provide significant control effect when EG203 was used as the rootstock.
\end{abstract}

Additional keywords: soilborne diseases

Bacterial wilt caused by race 1 strains of Ralstonia solanacearum is a destructive and widespread soilborne disease that limits tomato production in the tropics and subtropics (4). Disease incidences of 15 to $55 \%$ have been reported in fresh market tomato in Taiwan during hot and humid seasons, causing over US\$12 million in losses annually (14). Race 1 strains are difficult to control because of their soilborne nature. Also, the wide host range (13), including many weed hosts, favors its widespread distribution and persistence in the environment (16). Chemical control for soilborne diseases is usually unsuccessful and uneconomic; furthermore, the only commercial pesticides available for controlling $R$. solanacearum are chemical fumigants $(6,7)$.

Host plant resistance has been a major strategy for managing bacterial wilt in tomato (16). Resistance sources have been identified and cultivars with different levels of resistance have been developed (37).

Corresponding author: Jaw-Fen Wang

E-mail: jfw@avrdc.org

Accepted for publication 30 January 2008.

doi:10.1094/PDIS-92-6-0909

(C) 2008 The American Phytopathological Society
However, resistance to bacterial wilt in tomato can be location specific (11) and strain specific $(28,36)$. Location specificity can be due to the presence of strains that vary in virulence. In Taiwan, all reported strains of $R$. solanacearum are race 1 and biovar 3 or 4 (18), but they are highly variable in virulence, which was demonstrated by the symptom expression on different plant species including, tomato $(19,21)$. Based on interactions with six host species, 50 isolates collected from various hosts in many areas of Taiwan were divided into eight groups, and they were highly variable in virulence (19). Large variation in virulence also was observed among 40 isolates from tomato when they were inoculated on six tomato lines differing in bacterial wilt resistance (21). Moreover, isolates with unusually high virulence were found that could completely overcome the resistance in Hawaii 7996 (21), a tomato line that showed stable resistance over many locations (45). Thus, not knowing the possible reaction of resistant planting materials in different locations is a major constraint in resistance deployment.

There are few tomato cultivars with good stable resistance and desired fruit qualities; therefore, the use of available resistant tomato or eggplant as rootstock to control the disease has been explored
$(27,35)$. Use of grafted seedlings with resistant rootstocks to control soilborne diseases has been practiced widely, particularly under intensive vegetable production $(20,25)$.

The relation between initial inoculum density and disease development confirmed that tomato bacterial wilt is a simple interest disease (31); hence, reducing initial inoculum can be an effective approach for controlling this disease. Researchers have evaluated the efficacy of various soil amendments (SAs) in controlling bacterial wilt caused by race 1 strains of the pathogen. Use of S-H mixture (1), urea alone (39), or urea and lime together $(5,32)$ to control bacterial wilt has been reported. However, the control efficacy was not consistent over locations or soils and was highly influenced by soil chemical properties (30).

The procedure tested in this study was developed for selecting locally adapted resistant rootstock materials and SAs. The first step in this procedure entailed analyzing virulence variation of local pathogen populations. Representative strains then were selected and used to conduct seedling screening. An incubation test was conducted to evaluate the pathogen-suppressing potential of SAs (urea and lime) under controlled conditions in order to assess their potential field efficacy. Integrating these two components in a local integrated disease management program would provide good sustainability of disease management. Therefore, the objectives of this study were to test the effectiveness of this preliminary screen and to determine the efficacy of integrating host plant resistance by using resistant rootstock and reducing initial inoculum by applying effective SAs for controlling tomato bacterial wilt in the field. A preliminary report of this study was published (26).

\section{MATERIALS AND METHODS}

Bacterial strains and inoculum preparation. In total, 50 isolates of $R$. solanacearum from wilted tomato plants were collected from each of the three major tomato production areas. Plants were collected from 10 fields at Chunglin Hsinchu in northern Taiwan during 2001, 3 fields at Hsinshe Taichung in central Taiwan during 2004, and 7 fields at Kuantien Tainan in southern Taiwan during 1998 to 2000 . In 
all, 4, 13, and 5 isolates were obtained from the plants collected in field experiment sites at Chunglin, Hsinshe, and Kuantien, respectively. All tested isolates belonged to race 1 and biovar 3 or 4 . Strains Pss4, Pss190, and Pss216 with known virulence (21) from the AVRDCThe World Vegetable Center (AVRDC) collection were used as references. All isolates were preserved in $30 \%$ glycerol at $-80^{\circ} \mathrm{C}$. Inoculum of each tested isolate was prepared separately for each experiment following the procedure described below. Isolates from stored cultures were streaked on 2,3,5-triphenyl tetrazolium chloride medium (24) and incubated at $30^{\circ} \mathrm{C}$ for 48 h. Several typical fluid white colonies with a pink center were selected and transferred onto one 523 medium plate (22). After incubation at $30^{\circ} \mathrm{C}$ for $24 \mathrm{~h}$, bacterial mass was suspended in sterilized distilled water and adjusted to an optical density of 0.3 at a wavelength of $600 \mathrm{~nm}$. This suspension contained about $10^{8} \mathrm{CFU} / \mathrm{ml}$.

Plant materials. Plants used for inoculations were tomato, Lycopersicon esculentum Mill. (now Solanum lycopersicum) cvs. Taichung-AVRDC No.10 (ASVEG10) and BF-Okitsu 101; lines CRA 66, Hawaii 7996, and Hawaii 7998; and accessions L180-1 and L390; and eggplant, S. melongena L. cv. Surya (EG203). ASVEG10 and L390 are susceptible to $R$. solanacearum and the others have different levels of resistance to the pathogen. Seed of tested plants were sowed directly in 7- or 9-cmdiameter plastic pots for virulence evaluation or rootstock screening, respectively. A steam-sterilized potting mixture consisting of field soil, sand, compost, and rice husk in a 3:1:2:1 ratio was used. One plant was kept in each pot. All plants were grown in a greenhouse or a screenhouse under natural light with a mean temperature range from 25 to $31^{\circ} \mathrm{C}$ or from 23 to $35^{\circ} \mathrm{C}$, respectively. Seedlings with four to six true leaves were used for inoculations. Grafted plants between ASVEG10 (scion) and Hawaii 7996 or EG203 (rootstock) were produced following the AVRDC protocol (3). A brief description of the method follows. Seedlings of rootstock and scion were raised separately in polystyrene trays (3-cm-diameter cell size) with Plantaflor PROFI potting mix (Plantaflor Humus, Verkaufs-GmbH, Germany). At the two- to three-true-leaf stage, stems of scion and rootstock plants were cut at a $30^{\circ}$ angle and joined with a 1-cm-long latex tube $\left(0.2-\mathrm{cm}\right.$ inner diameter and cut at a $30^{\circ}$ angle). The grafted seedlings were healed in a shaded chamber at 25 to $32^{\circ} \mathrm{C}$ and relative humidity greater than $85 \%$ for 1 week, then moved to a screenhouse for hardening for 1 to 2 weeks before transplanting. Both grafted and nongrafted seedlings at the four- to six-true-leaf stage were transplanted in the field at the same time. The latex tube at the joint of grafted plants was not removed as it hardened, cracked, and eventually fell off.

Determination of virulence of local isolates. To investigate local isolate variation in virulence, 50 isolates each from Chunglin, Hsinshe, and Kuantien were selected and inoculated individually on three tomato lines. The lines were L390, L180-1, and Hawaii 7996 representing a susceptible, moderately resistant, and resistant host, respectively. Virulence was evaluated in the greenhouse by the soil drenching method (11). Tomato seedlings with four to six true leaves in individual 7$\mathrm{cm}$-diameter pots were inoculated by pouring $20 \mathrm{ml}$ of inoculum around the stem base. Inoculated plants with the same isolate were placed in a plastic flat with spacing between flats of at least $15 \mathrm{~cm}$. Isolates from each production area were tested in separate experiments in the same greenhouse with a mean temperature of 27 to $31^{\circ} \mathrm{C}$. Each experiment was conducted using a randomized complete block design (RCBD) with two replications and six plants per replication. All experiments were conducted once. The percentage of wilted plants was recorded once a week up to 28 days after inoculation. The final percentage of wilted plants for each isolate in each population and the three reference strains on the three tomato lines were analyzed with cluster analysis using the average linkage method and the three clustering criteria (cubic clustering criterion,
pseudo-F, and pseudo- $\mathrm{t}^{2}$ ) by the Statistical Analysis System (SAS Institute, Cary, NC).

Resistance of tomato and eggplant rootstocks against local strains. Four resistant tomato lines, BF-Okitsu 101, CRA 66, Hawaii 7996, and Hawaii 7998, and one resistant eggplant cultivar, EG203, were identified as potential wilt-resistant rootstocks through previous research (27). They were evaluated against two or three selected local strains from each production area. Inoculation of tomato plants was conducted as described above for virulence evaluation. Inoculation of eggplant seedlings was conducted similarly to that for tomato seedlings, except that one side of the roots was cut about 1 to $2 \mathrm{~cm}$ away from the stem base with a knife prior to drenching with the bacterial suspension. The experiment was conducted by a splitplot design with strain as the main factor and cultivar as the subfactor. There were three replications and 12 plants per replication. All experiments were conducted once. Susceptible tomato accession L390 was used as the control. The percentage of wilted plants was recorded once a week up to 3 weeks after inoculation. Mean temperature ranged from 25 to $30^{\circ} \mathrm{C}$ in the greenhouse during the experiments. Disease incidence was transformed to the arcsine of the square root for analysis of variance (ANOVA) and Fisher's least significant difference (LSD) $t$ test.

Evaluation of SA. Incubation experiments were conducted to determine the effect of urea and lime mixture on strain Pss4 survival in the soils collected from the four field experiment sites at Wenlin Chunglin (WL), Tungchuang Kuantien (TC), AVRDC, and Taiwan Seed Improvement and Propagation Station (TSS) (Table 1). In this study, quick lime, $\mathrm{CaO}$, was replaced by slaked lime, $\mathrm{Ca}(\mathrm{OH})_{2}$, because $\mathrm{CaO}$ is high alkaline and corrosive and the suppressive effect of both in tested soils were not significantly different (data not shown). Preliminary studies revealed that $0.0412 \%$ urea and $0.1996 \% \mathrm{Ca}(\mathrm{OH})_{2}$ had the most stable effects over soil types (data not shown). Therefore, $0.206 \mathrm{~g}$ of urea and

Table 1. Information about sites where field experiments were conducted ${ }^{\mathrm{a}}$

\begin{tabular}{|c|c|c|c|c|c|c|c|c|c|c|}
\hline \multirow[b]{2}{*}{ Site $^{c}$} & \multirow[b]{2}{*}{$\begin{array}{c}\text { Altitude } \\
\text { (m) }\end{array}$} & \multicolumn{3}{|c|}{ Meteorological data ${ }^{b}$} & \multirow[b]{2}{*}{$\begin{array}{c}\text { Soil texture } \\
\text { (\% sand/silt/clay) }\end{array}$} & \multirow[b]{2}{*}{$\mathbf{p H}^{\mathbf{d}}$} & \multirow[b]{2}{*}{$\begin{array}{c}\text { CEC } \\
(\mathrm{cmol} / \mathrm{kg})\end{array}$} & \multirow[b]{2}{*}{$\begin{array}{l}\text { OC } \\
(\%)\end{array}$} & \multirow[b]{2}{*}{$\begin{array}{l}\text { TN } \\
(\%)\end{array}$} & \multirow[b]{2}{*}{$\begin{array}{l}\text { OM } \\
(\%)\end{array}$} \\
\hline & & $\begin{array}{l}\text { Temp } \\
\left({ }^{\circ} \mathbf{C}\right)\end{array}$ & $\begin{array}{l}\text { RH } \\
(\%)\end{array}$ & $\begin{array}{c}\text { Precip } \\
(\mathbf{m m})\end{array}$ & & & & & & \\
\hline Wenlin Chunglin (WL) & $50-60$ & $30 / 23$ & 75 & 67 & $19 / 58 / 23$ & 5.4 & 10.7 & 1.86 & 0.15 & 3.21 \\
\hline Tungchuang Kuantien (TC) & $10-20$ & $29 / 20$ & 71 & 75 & $18 / 62 / 20$ & 6.0 & 10.5 & 0.98 & 0.11 & 1.69 \\
\hline AVRDC Tainan (AVRDC) & 14 & $32 / 24$ & 69 & 972 & $56 / 32 / 12$ & 7.1 & 7.0 & 0.43 & 0.07 & 0.73 \\
\hline TSS Hsinshe (TSS) & 470 & $24 / 15$ & 68 & 259 & $30 / 38 / 32$ & 5.2 & 10.4 & 1.27 & 0.16 & 2.18 \\
\hline
\end{tabular}

${ }^{a}$ Soil texture, cation exchange capacity (CEC), organic carbon (OC), total nitrogen (TN), and organic matter (OM) were determined by the Soil Survey and Testing Center, National Chung Hsing University, Taichung, Taiwan.

${ }^{\mathrm{b}}$ Meteorological data during the experimental period; Temp = mean temperature (maximum to minimum), $\mathrm{RH}=$ mean relative humidity $(\mathrm{RH})$, Precip $=$ precipitation.

c The field experiment sites, WL, TC, AVRDC, and TSS, were located in Chunglin of Hsinchu county in northern Taiwan; in Kuantien of Tainan county in southern Taiwan; in the AVRDC research farm, Shanhua of Tainan county in southern Taiwan; and in the research farm of Taiwan Seed Improvement and Propagation Station located at Hsinshe, Taichung county in central Taiwan, respectively.

${ }^{\mathrm{d}} \mathrm{pH}$ was determined by mixing air dried soil with $0.01 \mathrm{M} \mathrm{CaCl}_{2}$ at a ratio of $1: 2(\mathrm{wt} / \mathrm{vol})(38)$. 
$0.998 \mathrm{~g}$ of $\mathrm{Ca}(\mathrm{OH})_{2}$ were added to $500 \mathrm{~g}$ of tested soil in this study. Soil samples were air dried, sieved through a 32-mesh screen, and stored at room temperature. To prepare infested soil, a suspension of Pss4 and each air-dried soil sample were mixed thoroughly at the ratio of $1: 10(\mathrm{vol} / \mathrm{wt})$ and placed in zipper bags. The final inoculum densities of infested WL, TC, AVRDC, and TSS soil were $1.3 \times 10^{7}, 2.8 \times 10^{7}, 2.2 \times$ $10^{7}$, and $1.4 \times 10^{7} \mathrm{CFU} / \mathrm{g}$ of dry soil, respectively. Urea, $\mathrm{Ca}(\mathrm{OH})_{2}$, and a mixture of urea and $\mathrm{Ca}(\mathrm{OH})_{2}$ were added separately to each bag containing infested soil and well mixed. Infested soil without SA was used as control. The experiment was conducted in a $30^{\circ} \mathrm{C}$ incubator without light and consisted of four treatments and three replications per treatment. One bag was used for one replication and the experiment was conducted once. The density of $R$. solanacearum in soil was measured every week for a 4-week period. For each measurement, $10 \mathrm{~g}$ of soil were taken from each bag, added to $90 \mathrm{ml}$ of sterile distilled water in a $250-\mathrm{ml}$ Erlenmeyer flask, and shaken at $200 \mathrm{rpm}$ for $30 \mathrm{~min}$. The suspensions were serially diluted with sterile distilled water and $0.1 \mathrm{ml}$ was spread on one plate of modified SM-1 medium $(9,43)$. Two plates were used for each dilution. The plates were incubated at $30^{\circ} \mathrm{C}$ for 2 to 3 days and typical $R$. solanacearum colonies with irregular edge, fluidal, and white with pink or red centers were counted. The detection limit of this selective medium is around $100 \mathrm{CFU} / \mathrm{g}$ of dry soil based on previous tests (data not shown). The number of CFU per gram of dry soil was converted into $\left(\log _{10}([\mathrm{x}+1])\right.$ for statistical analysis due to the repeated measurements of the same samples.

Field experiments. Field research sites were located at two commercial fields at WL and TC and two research farms of AVRDC and TSS in Taiwan (Table 1). The WL and TC fields have similar cropping systems, with paddy rice grown in spring or summer before tomato. Both sites had a history of tomato bacterial wilt, and a severe outbreak occurred in fall 2002. In order to maintain pathogen density in the experiment site, cherry tomato and yardlong bean, instead of paddy rice, were cultivated during winter 2002 to spring 2003 at the WL and TC sites, respectively. At AVRDC, the experiment was conducted in an artificial disease nursery (31). At TSS, soil was naturally infested and routinely has been used for screening of resistant materials to bacterial wilt. The six treatments selected based on the preliminary screen results were combinations of SA application and three planting materials, ASVEG10, ASVEG10 grafted on EG203 rootstock, and ASVEG10 grafted on Hawaii 7996 rootstock. The application amount of SA was calculated by assuming SA will be incorporated to a $20-\mathrm{cm}$ depth and the soil bulk density will be equal to one (32). Therefore, the SA was applied once at a rate of urea at $825 \mathrm{~kg} / \mathrm{ha}$ (equal to $\mathrm{N}$ at $379.5 \mathrm{~kg} / \mathrm{ha}$ ) and $\mathrm{Ca}(\mathrm{OH})_{2}$ at 3,993 $\mathrm{kg} / \mathrm{ha}$. Treatments with SA received the same application of basal fertilizer. The experiment was arranged in an RCBD with three replications. The plot size was 22 by $1.5 \mathrm{~m}$ and there were two rows and 100 plants per plot, with a spacing of $45 \mathrm{~cm}$ between plants. On-farm experiments started with the application of SA on 14 July 2003, 15 August 2003, 4 June 2004, and 27 July 2004 at WL, TC, AVRDC, and TSS sites, respectively. Taifer Effective No.2 Organic Compound Fertilizer (14:7:7:4:45, N-P-K-Mg-organic matter) (Taifer Taiwan Fertilizer Co., Taiwan) at 2 t/ha was used as the basal fertilizer. After application of basal fertilizer, SA was scattered evenly on the soil surface by hand in the treated plots and incorporated with a rotary plow. Afterward, beds were built and immediately mulched with silverblack polyethylene film. The pathogen density in the soil at each experiment site was measured right before the application of basal fertilizer and SA and then before transplanting. Soil samples were collected from 10 randomly selected points per plot from a depth of 5 to $20 \mathrm{~cm}$ with a $3-\mathrm{cm}$ diameter soil auger, then mixed thoroughly in a bag to form a sample. The pathogen density was measured as described above in the "Evaluation of SA" section. Preliminary studies revealed that urea could be phytotoxic when high concentrations of ammonia or nitrite accumulated during nitrification of urea in the soil. To avoid such phytotoxicity, seedlings were transplanted about 1 month after SA application, and all experiments ended 105 days after transplanting. Disease incidence was recorded every 3 weeks until the end of each experiment. The relative area under the disease progress curve (RAUDPC) was calculated as described by Fry (8). $\mathrm{RAUDPC}=\Sigma_{i=0}$ to $n\left[\left(Y_{i+1}+Y_{i}\right) / 2\right]\left(X_{i+1}-\right.$ $\left.X_{i}\right) / T$, where $Y_{i}=$ the percentage of wilted plants at the $i$ th observation, $X_{i}=$ time (days) after transplanting at the $i$ th observation, $n=$ total number of observations, and $T=$ the number of days from transplanting to the end of the observation period. Marketable yield was calculated

Table 2. Mean final percentage of wilted plants determined in a preliminary screen expressed on tomato lines caused by Ralstonia solanacearum isolates in three local populations collected from Chunglin, Kuantien, and Hsinshe under greenhouse conditions

\begin{tabular}{|c|c|c|c|}
\hline \multirow[b]{2}{*}{ Virulence group $^{a}$} & \multicolumn{3}{|c|}{ Tomato lines (\%) } \\
\hline & L390 & L180-1 & Hawaii 7996 \\
\hline Chunglin population (50) & $91.5 \pm 11.0^{\mathrm{b}}$ & $28.8 \pm 22.2$ & $20.3 \pm 17.4$ \\
\hline \multicolumn{4}{|l|}{ Group $1(0)$} \\
\hline Pss190 & 100.0 & 83.5 & 75.0 \\
\hline Group 2 (5) & $98.3 \pm 3.7^{\mathrm{b}}$ & $68.3 \pm 16.0$ & $11.7 \pm 13.9$ \\
\hline Pss4 & 100.0 & 66.7 & 0.0 \\
\hline CLshis3 & 100.0 & 91.5 & 17.0 \\
\hline Group 3 (14) & $88.7 \pm 10.6$ & $43.5 \pm 14.3$ & $37.5 \pm 15.6$ \\
\hline CLss 2 & 91.5 & 33.0 & 58.5 \\
\hline Group 4 (31) & $91.7 \pm 11.6$ & $15.9 \pm 12.0$ & $14.0 \pm 13.2$ \\
\hline Pss216 & 58.3 & 8.3 & 8.3 \\
\hline CLss 7 & 100.0 & 25.0 & 33.0 \\
\hline Hsinshe population (50) & $60.0 \pm 25.3$ & $5.5 \pm 8.7$ & $3.7 \pm 6.6$ \\
\hline \multicolumn{4}{|l|}{ Group $1(0)$} \\
\hline Pss190 & 100.0 & 100.0 & 58.4 \\
\hline Group 2 (16) & $91.1 \pm 9.4$ & $5.2 \pm 10.5$ & $0.5 \pm 2.1$ \\
\hline Pss4 & 100.0 & 41.7 & 0.0 \\
\hline$H S d n 13$ & 83.4 & 25.0 & 8.3 \\
\hline Group 3 (34) & $45.3 \pm 14.8$ & $5.6 \pm 7.9$ & $5.2 \pm 7.4$ \\
\hline Pss216 & 50.0 & 0.0 & 8.3 \\
\hline HSsj10 & 33.3 & 0.0 & 16.7 \\
\hline Kuantien population (50) & $97.7 \pm 5.3$ & $26.0 \pm 24.4$ & $4.8 \pm 11.4$ \\
\hline Group 1 (1) & 100.0 & 91.7 & 58.3 \\
\hline Pss190 & 100.0 & 94.5 & 77.8 \\
\hline Group 2 (3) & $100.0 \pm 0.0$ & $88.9 \pm 12.7$ & $30.5 \pm 12.7$ \\
\hline KThs2 & 100.0 & 75.0 & 41.7 \\
\hline Group 3 (14) & $100.0 \pm 0.0$ & $39.9 \pm 8.7$ & $3.6 \pm 5.4$ \\
\hline Pss4 & 100.0 & 52.8 & 2.8 \\
\hline KTcc5 & 100.0 & 50.0 & 0.0 \\
\hline Group 4 (31) & $97.0 \pm 5.1$ & $12.1 \pm 9.6$ & $1.1 \pm 3.6$ \\
\hline$K T l s 16$ & 100.0 & 25.0 & 0.0 \\
\hline Group 5 (1) & 75.0 & 8.3 & 8.3 \\
\hline Pss216 & 72.3 & 2.8 & 11.2 \\
\hline
\end{tabular}

a Virulence groups of local isolates were determined by the average linkage method with three clustering criteria by SAS. The number of local isolates in each population or group is indicated in parentheses. Reference strains (boldface) Pss190, Pss4, and Pss216 were included in the cluster analysis and listed under their clustered group. The named strains (italic font) of each group were selected as representatives, which were used for evaluation of planting materials.

b Mean and standard deviation of disease incidence caused by local isolates of specific population or group (excluded reference strains) in each tomato line. 
based on harvests during a 42-day period starting 2 months after transplanting. For fruit quality measurements, one mature fruit per plant was picked from all plants carrying fruit in the same plot 76 days after transplanting. All fruit from the same plot were mixed as one sample. Fruit quality measurements included fruit weight, soluble solids $\left(\right.$ Brix $\left.^{\circ}\right)$ (12), and acidity (percent citric acid) (17) were conducted by the Nutrition Unit, AVRDC. ANOVA was conducted to determine the effect of the treatments on disease incidence, RAUDPC, tomato yield, and fruit quality using SAS. Means were compared by LSD at $P=0.05$.

\section{RESULTS}

Virulence of local isolates. Variation in virulence was observed in all three tested local populations of $R$. solanacearum based on the final disease incidence on three tomato lines. Judging each population as a whole, Chunglin and Kuantien populations showed similar levels of virulence, which were higher than the Hsinshe population based on the mean percentage of wilted plants for all isolates on each line (Table 2). Results of cluster analysis suggested two to five virulence groups in each local population. Kuantien population had the largest variation, because it contained isolates with virulence as high as Pss190 as well as isolates as weak as Pss216. The sole isolate in group 1 of the Kuantien population displayed an average final wilt of $83.3 \%$ and was the most virulent isolate found. In all three tested populations, isolates of the predominant groups were all clustered together with either Pss4 or Pss216. This suggests that Hawaii 7996 still can provide good resistance against most of the isolates in these three areas. The resistance of Hawaii 7996, however, would be the least stable in the Chunglin region, because 14 of 50 isolates caused $37.5 \%$ wilting on Hawaii 7996. One isolate each from predominant groups of each population was selected randomly to chal- lenge the resistant plant genotypes described below.

Reactions of rootstock cultivars and lines against local strains. To evaluate potential rootstock cultivars and lines, representative strains selected from the Chunglin, Kuantien, and Hsinshe populations according to their virulence profile were used to challenge resistant tomato and eggplant cultivars and lines. Results of analyses showed that interactions were significant between the main factor (strains) and subfactor (tested lines); thus, the mean comparison was conducted by individual strain or line. All plants of the susceptible control, L390, were wilted by all tested strains except CLss2, a strain selected from group 3 of Chunglin population (Table 3). Strains in group 3 of Chunglin population had lower virulence on L390 (Table 2). Overall, Chunglin representative strains expressed similar or higher mean final percent wilted plants for the six cultivars and lines examined than Kuantien and Hsinshe representative strains (Table 3 ). The much higher severity caused by strain HSsj10 on L390 and Hawaii 7996 could be due to higher relative humidity in this experiment compared with the experiment assessing virulence (Table 2). Eggplant cv. EG203 expressed the highest level of resistance ( 0 to $8.4 \%$ mortality) to all tested strains (Table 3 ). Responses on tomato lines were much less consistent. Among the four tested tomato rootstocks, Hawaii 7996 showed the highest resistance against eight of the nine tested strains and was the most stable resistant tomato rootstock. Hawaii 7998 was the second most stable resistant rootstock, while the others only provided good resistance against two to four strains. However, mortality on Hawaii 7996 was high when challenged with strains CLss2, CLss7, and HSsj10 (38.9 to $66.7 \%$ ). Interestingly, CRA66 seemed to complement Hawaii 7996, because it showed good resistance against these three strains (Table 3 ).
Efficacy of SA to suppress pathogen in local soils. Suppression of $R$. solanacearum by urea and $\mathrm{Ca}(\mathrm{OH})_{2}$, used alone or together, was evaluated at $30^{\circ} \mathrm{C}$ using soil samples collected from WL, TC, AVRDC, and TSS sites. During the 28-day period, pathogen density remained at the level of $10^{7} \mathrm{CFU} / \mathrm{g}$ of dry soil in the control treatment of all tested soils (Fig. 1). Maximum suppressive effect of different amendments in different soils was observed 3 or 4 weeks after treatments. Suppression by each SA varied greatly among tested soils. The mixture of urea and $\mathrm{Ca}(\mathrm{OH})_{2}$ showed the highest suppressive effect in WL, AVRDC, and TSS soils but not in TC soil (Fig. 1). Urea alone gave the greatest suppressive effect in the TC and AVRDC soils. Amending with $\mathrm{Ca}(\mathrm{OH})_{2}$ alone had no effect in decreasing $R$. solanacearum densities in TC and TSS soils and only a small effect in WL soil (Fig. 1). However, in the AVRDC soil, $R$. solanacearum cells decreased to an undetectable level. Overall, the mixture of urea and $\mathrm{Ca}(\mathrm{OH})_{2}$ or urea alone showed better suppressive effect than $\mathrm{Ca}(\mathrm{OH})_{2}$ alone in the different soil samples.

Field experiments. Based on the results of preliminary screens on the profiles of local strains, resistance of rootstocks, and pathogen-suppressing efficacy of SA, field experiments consisting of six treatments were designed and conducted at four locations (Table 4). Before applying the SA, the range of initial inoculum density in experiment sites was $1.2 \times 10^{3}$ to $5.8 \times 10^{4}$ CFU/g of dry soil in WL, undetectable to $3.8 \times 10^{2}$ in TC, $5.0 \times 10^{4}$ to $4.7 \times 10^{6}$ in AVRDC, and $1.1 \times 10^{3}$ to $3.4 \times 10^{4}$ in TSS. At transplanting time (about 1 month after SA treatment), the range of inoculum density in the SA-treated plots was undetectable to $4.1 \times 10^{2} \mathrm{CFU} / \mathrm{g}$ of dry soil in $\mathrm{WL}$, undetectable in $\mathrm{TC}$, undetectable to $3.3 \times 10^{3}$ in AVRDC, and undetectable to $1.3 \times 10^{2}$ in TSS, whereas the pathogen density in the SA-nontreated plots changed

Table 3. Bacterial wilt incidence on potential tomato and eggplant rootstock lines caused by Ralstonia solanacearum strains (indicated with bold and italic fonts) selected from predominant groups of three local pathogen populations

\begin{tabular}{|c|c|c|c|c|c|c|c|c|c|c|}
\hline \multirow[b]{3}{*}{ Line } & \multicolumn{10}{|c|}{ Mean final percentage of wilted plants $(\%)^{\mathrm{a}}$} \\
\hline & \multicolumn{3}{|c|}{ Chunglin $^{\mathrm{b}}$} & \multicolumn{3}{|c|}{ Kuantien ${ }^{b}$} & \multirow{2}{*}{$\begin{array}{c}\text { Control } \\
\text { Pss4 }\end{array}$} & \multicolumn{2}{|c|}{ Hsinshe $^{b}$} & \multirow{2}{*}{$\begin{array}{c}\text { Control } \\
\text { Pss4 }\end{array}$} \\
\hline & CLshis3 & CLss2 & CLss 7 & KThs 2 & KTcc5 & KTls16 & & HSdn13 & HSsj10 & \\
\hline EG203 & $12.2(8.4)$ & $0.3(0.0)$ & $0.3(0.0)$ & $0.3(0.0)$ & $0.3(0.0)$ & $12.2(8.4)$ & $0.3(0.0)$ & $11.3(5.5)$ & $0.3(0.0)$ & $19.2(11.1)$ \\
\hline Hawaii 7996 & $34.6(33.4)$ & $49.9(58.4)$ & $55.4(66.7)$ & $12.2(8.4)$ & $0.3(0.0)$ & $0.3(0.0)$ & $29.7(25.0)$ & $24.1(16.7)$ & $38.6(38.9)$ & $13.7(8.3)$ \\
\hline Hawaii 7998 & $45.0(50.0)$ & $67.3(75.0)$ & $67.3(75.0)$ & $34.6(33.4)$ & $0.3(0.0)$ & $0.3(0.0)$ & $24.1(16.7)$ & $33.2(30.6)$ & $58.5(72.2)$ & $19.2(11.1)$ \\
\hline BF-Okitsu 101 & 77.8 (91.6) & $29.7(25.0)$ & $40.1(41.7)$ & $45.0(50.0)$ & $49.9(58.4)$ & $34.6(33.4)$ & $65.9(83.3)$ & nt & nt & nt \\
\hline CRA 66 & 77.8 (91.6) & $29.7(25.0)$ & $22.7(25.0)$ & $67.3(75.0)$ & $40.1(41.7)$ & $34.6(33.4)$ & $65.9(83.3)$ & $38.6(38.9)$ & $25.6(19.4)$ & $57.3(69.4)$ \\
\hline L390 (Sus.) & $89.7(100.0)$ & $72.2(83.3)$ & $89.7(100.0)$ & 89.7 (100.0) & 89.7 (100.0) & $89.7(100.0)$ & 89.7 (100.0) & 89.7 (100.0) & 89.7 (100.0) & $89.7(100.0)$ \\
\hline Mean & $56.2(62.5)$ & $41.5(44.5)$ & $45.9(51.4)$ & $41.5(44.5)$ & $30.1(33.4)$ & $28.6(29.2)$ & $45.9(51.4)$ & $39.4(38.3)$ & $42.5(46.1)$ & $39.8(40.0)$ \\
\hline
\end{tabular}

a Disease incidence was transformed to the arcsine of the square root for analysis of variance and mean comparison. Actual data are presented in parentheses; $\mathrm{nt}=$ not tested. The evaluation against strains from Chunglin and Kuantien was conducted jointly in a greenhouse at 26 to $29^{\circ} \mathrm{C}$ mean temperature range and 60 to $89 \%$ mean relative humidity $(\mathrm{RH})$ range. The evaluation against strains from Hsinshe was conducted in a separate greenhouse experiment at 24 to $30^{\circ} \mathrm{C}$ mean temperature range and 65 to $94 \%$ mean $\mathrm{RH}$ range.

b Fisher's least significant difference (LSD), based on transformed values for comparison of two-line-means at each strain or two-strain means at each line, was calculated at $P<0.05$. For Chunglin and Kuantien, strain $\times$ line $(P>\mathrm{F})<0.0001$, LSD (two-line means) at each strain $=21.7$, and LSD (two-strain means) at each line $=28.2$. For Hsinshe, strain $\times$ line $(P>F)<0.0001$, LSD (two-line means) at each strain $=10.4$, and LSD $($ two-strain means $)$ at each line $=11.8$. 
slightly and remained at a similar level. During the 105-day experiment period, disease development of all treatments followed a sigmoid pattern, and maximum incidence was observed at 63 or 84 days after transplanting (data not shown). Variable disease pressure occurred among the experiments based on the final disease incidence measured in the control treatment ASVEG10, where mean final percentage of wilted plants ranged from $24.4 \%$ in TSS to $92.9 \%$ in WL (Table 4).

ANOVA using either transformed final disease incidence or RAUDPC data indicated that the effect of plant material was significant in all experiments. The SA effect was significant on nongrafted plants and Hawaii 7996-grafted plants in the AVRDC and TSS experiments, respectively, using transformed final disease incidences. Significant SA effect was detected more frequently when using RAUDPC data. In WL and TSS sites, it was significant over tested lines whereas, in AVRDC site, only on nongrafted plants (Table 4). Significant interaction between the two factors was detected only at the AVRDC site with disease incidence data type. Eggplant rootstock EG203 was most effective at reducing final wilt incidence and suppressing disease development. Disease control with Hawaii 7996 rootstock was either similar to or significantly lower than control with EG203, but it still provided significant control under high and low disease pressure. The SA effect was more obvious in suppressing disease development than in reducing final incidence, particularly under moderate disease pressure. Tomato yield and fruit quality data were assessed only at the WL and TC sites. There was no significant difference for these variables between the treatments with SA and without SA. However, grafting onto resistant rootstock could increase yield drastically compared with the nongrafted control in the WL experiment, where disease pressure was high (Table 5). Although eggplant rootstock provided better disease control than tomato rootstock, it did not generate significantly higher yield than that of tomato rootstock. Effects of both rootstocks on fruit quality were not consistent over the two experiments. Fruit from the treatments with EG203 rootstock at WL had significantly higher Brix $^{\circ}$ and citric acid compared with those from Hawaii 7996 based on mean values, but the TC site had significantly smaller fruit size (Table 5).

\section{DISCUSSION}

Control of tomato bacterial wilt caused by race 1 strains of $R$. solanacearum is a great challenge because of the broad host range of the pathogen and its soilborne nature. The challenge is even greater in the tropics and subtropics, because the hot and humid environments favor disease development and pathogen survival. Host resis- tance has been considered the most effective strategy to control this disease but its application has been limited due to the presence of large variations in virulence of the diverse race 1 strains (21). The use of SA to reduce initial inoculum is another main approach to control soilborne diseases. However, efficacy of SA for tomato bacterial wilt has been shown to be soil dependent $(30,32)$. To date, no single control method has provided effective and long-term control of tomato bacterial wilt. Thus, this study was conducted to test the effectiveness of a preliminary screen system in order to control the strain and soil factors when designing a local integrated management program for tomato bacterial wilt.

Variation in virulence was determined for three $R$. solanacearum populations collected from three tomato production areas in Taiwan. Based on the final disease severity recorded on three tomato lines, two to five virulence groups could be found in each population. The results confirmed earlier studies in French West Indies and Taiwan that race 1 strains are variable in virulence $(21,36)$. However, each population is unique in its degree of variation as well as in the presence of strains with special interactions with the tested tomato lines. For example, in this study, the Kuantien population showed the largest variation and had a strain with the highest virulence whereas the Hsinshe population showed the lowest virulence. Group 3 strains of the Chunglin population were unique because they were highly virulent on Hawaii 7996 compared with other strains but the disease incidences they caused on L180-1 and L390 were lower than expected. These results further support the location-specific nature of resistance to bacterial wilt in tomato which mainly is due to the presence of strains with different virulence $(28,36)$. The variation observed in this study could be related to the different selection pressures present in different agroecological environments, where soil property, cropping system, host genotypes, local weeds, or microbe flora differed (33). Furthermore, genetic recombination and horizontal gene transfer may play an important role in the genetic differentiation of soilborne bacteria (15). Although $R$. solanacearum is capable of acquiring foreign DNA fragments $(2,23)$, the importance of genetic recombination on shaping population structure remains to be determined.

Local representative strains of $R$. solanacearum were used to evaluate resistance to bacterial wilt of potential rootstock cultivars at the seedling stage.

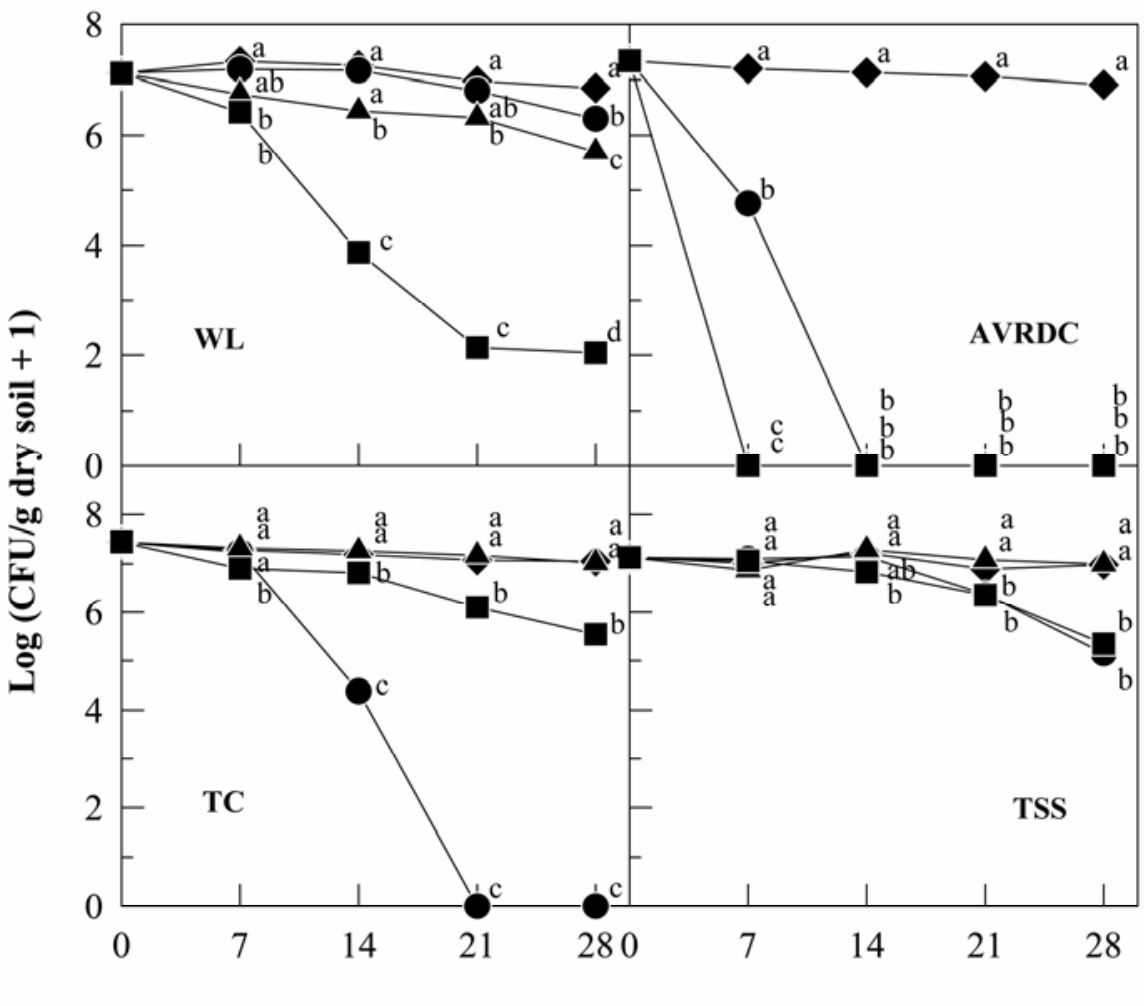

Days after treatment

Fig. 1. Population dynamics of Ralstonia solanacearum in soil samples collected from the four field experiment sites after amending with $0.0412 \%$ urea $(\bullet), 0.1996 \% \mathrm{Ca}(\mathrm{OH})_{2}(\mathbf{\Delta})$, or a mixture of both (匹) at $30^{\circ} \mathrm{C}$. Sites are Wenlin Chunglin (WL), Tungchuang Kuantien (TC), AVRDC Tainan (AVRDC), and TSS Hsinshe (TSS). Soils without soil amendment were used as the control ( $)$. Mean comparisons were conducted at each sampling time by treatments. Means with the same letter were not significantly different $(P=0.05)$ by repeated measures analysis 
Selected resistant rootstocks then were evaluated for resistance to bacterial wilt in the field. A good correlation between the seedling screening and the field results was found. For example, Hawaii 7996 was moderately resistant in the greenhouse to strains from Chunglin, and similar results also were obtained in the WL field experiment at Chunglin. EG203 seemed to have high and stable resistance against all strains originating from the three areas, and grafting on EG203 rootstock gave the best and most stable control of the disease in all field experiments. Previous results (11) also have shown a significant positive correlation between resistance of tomato screened at the seedling stage under controlled conditions and in field experiments in various locations. Thus, it can be concluded that the seedling screening method described in the present study can be used effectively to select resistant materials that can be used for breeding or grafting purposes. An earlier study has shown that
EG203 is resistant to root-knot nematode caused by Meloidogyne incognita and highly resistant to Fusarium wilt caused by Fusarium oxysporum f. sp. lycopersici (47). Therefore, EG203 can be recommended for controlling these three important soilborne diseases.

Urea and lime have been used alone or in combination with other compounds to control soilborne diseases, including bacterial wilt $(1,5,32,39,42)$. For example, preplanting application of hydrated lime reduces clubroot severity and increases yield of cauliflower (42). Amending soil with urea alone could effectively control bacterial wilt caused by race 1 strains of the pathogen in tobacco (39), while amending urea and lime in an integrated package was found effective in controlling the disease in potato (5). However, these studies were conducted with only one type of soil or in a single location, and the effect of soil or location on control efficacy was never considered. Depending on the soil, adding urea, slaked lime, or both together had different effects on the $R$. solanacearum population dynamics. Michel et al. (32) had indicated the location effect in using SA to control tomato bacterial wilt, and they have further dissected the disease control mechanisms (30). In general, results of the current study agreed with their findings. Amending with urea alone could reduce the pathogen to undetectable level in soils collected from TC and AVRDC sites. This may be related to the accumulation of nitrite during urea decomposition, and its toxicity was enhanced due to a decrease in soil $\mathrm{pH}$ at the same time (30). The suppressive effect from amending $\mathrm{Ca}(\mathrm{OH})_{2}$ alone could be due purely to its effect in increasing soil $\mathrm{pH}$. The $\mathrm{pH}$ of AVRDC soil after amending with $\mathrm{Ca}(\mathrm{OH})_{2}$ could be retained around 9 for a period, and such an environment is toxic to $R$. solanacearum (30). The significant and large reduction in $R$. solanacearum population by urea and $\mathrm{Ca}(\mathrm{OH})_{2}$ mixture in the

Table 4. Effect of resistant rootstock and soil amendment (SA) alone or together on the mean final percentage of wilted plants and relative area under the disease progress curve (RAUDPC) in field experiments conducted at four sites ${ }^{\mathrm{a}}$

\begin{tabular}{|c|c|c|c|c|c|c|c|c|}
\hline \multirow[b]{2}{*}{ Site, materials ${ }^{b}$} & \multicolumn{4}{|c|}{ Wilted plants (\%) } & \multicolumn{4}{|c|}{ RAUDPC } \\
\hline & $\mathbf{S A}$ & w/o SA & Mean & Difference $^{c}$ & SA & w/o SA & Mean & Difference $^{c}$ \\
\hline \multicolumn{9}{|l|}{ WL } \\
\hline EG203 & $4.6(0.9)$ & $9.4(2.8)$ & $7.0(1.8)$ & $4.8 \mathrm{~ns}$ & $0.15(0.4)$ & $0.37(1.5)$ & $0.26(1.0)$ & $0.22 \mathrm{~ns}$ \\
\hline Hawaii 7996 & $24.8(18.4)$ & $43.6(47.2)$ & $34.2(32.8)$ & $18.8 \mathrm{~ns}$ & $0.94(8.3)$ & $1.36(24.2)$ & $1.15(16.2)$ & $0.42 * *$ \\
\hline Nongrafted & $73.5(88.4)$ & $78.3(92.9)$ & $75.9(90.6)$ & $4.8 \mathrm{~ns}$ & $1.74(54.5)$ & $1.81(64.5)$ & $1.78(59.5)$ & $0.07 \mathrm{~ns}$ \\
\hline Mean & $34.3(35.9)$ & $43.8(47.6)$ & $\ldots$ & $9.5 \mathrm{~ns}$ & $0.94(21.1)$ & $1.18(30.0)$ & $\ldots$ & $0.24 * *$ \\
\hline $\mathrm{SA}$ & $P=0.1117$ & $\ldots$ & $\ldots$ & $\ldots$ & $P=0.0046$ & $\ldots$ & $\ldots$ & $\ldots$ \\
\hline $\mathrm{P}$ & $P<0.0001$ & $\ldots$ & $\ldots$ & $\ldots$ & $P<0.0001$ & $\ldots$ & $\ldots$ & $\ldots$ \\
\hline $\mathrm{SA} \times \mathrm{P}$ & $P=0.5022$ & $\ldots$ & $\ldots$ & $\ldots$ & $P=0.1437$ & $\ldots$ & $\ldots$ & $\ldots$ \\
\hline LSD & 20.9 & $\ldots$ & 14.8 & $\ldots$ & 0.25 & $\ldots$ & 0.18 & $\ldots$ \\
\hline \multicolumn{9}{|l|}{$\mathrm{TC}$} \\
\hline EG203 & $3.0(0.7)$ & $5.3(2.3)$ & $4.1(1.5)$ & $2.3 \mathrm{~ns}$ & $0.10(0.4)$ & $0.21(1.0)$ & $0.16(0.7)$ & $0.11 \mathrm{~ns}$ \\
\hline Hawaii 7996 & $17.5(16.5)$ & $14.8(9.9)$ & $16.1(13.2)$ & $-2.7 \mathrm{~ns}$ & $0.56(7.4)$ & $0.52(5.0)$ & $0.54(6.2)$ & $-0.04 \mathrm{~ns}$ \\
\hline Nongrafted & $34.2(34.8)$ & $41.3(40.8)$ & $37.8(37.8)$ & $7.1 \mathrm{~ns}$ & $0.98(17.7)$ & $1.07(22.7)$ & $1.02(20.2)$ & $0.09 \mathrm{~ns}$ \\
\hline Mean & $18.2(17.4)$ & $20.5(17.7)$ & $\ldots$ & $2.3 \mathrm{~ns}$ & $0.55(8.5)$ & $0.60(9.5)$ & $\ldots$ & $0.05 \mathrm{~ns}$ \\
\hline $\mathrm{SA}$ & $P=0.7058$ & $\ldots$ & $\ldots$ & $\ldots$ & $P=0.5900$ & $\ldots$ & $\ldots$ & $\ldots$ \\
\hline $\mathrm{P}$ & $P=0.0024$ & $\ldots$ & $\ldots$ & $\ldots$ & $P=0.0002$ & $\ldots$ & $\ldots$ & $\ldots$ \\
\hline $\mathrm{SA} \times \mathrm{P}$ & $P=0.7913$ & $\ldots$ & $\ldots$ & $\ldots$ & $P=0.8298$ & $\ldots$ & $\ldots$ & $\ldots$ \\
\hline LSD & 22.3 & $\ldots$ & 15.7 & $\ldots$ & 0.41 & $\ldots$ & 0.29 & $\ldots$ \\
\hline \multicolumn{9}{|l|}{ AVRDC } \\
\hline EG203 & $0.3(0.0)$ & $3.1(0.7)$ & $1.7(0.4)$ & $2.8 \mathrm{~ns}$ & $0.00(0.0)$ & $0.11(0.4)$ & $0.05(0.2)$ & $0.11 \mathrm{~ns}$ \\
\hline Hawaii 7996 & $22.5(15.0)$ & $24.5(17.5)$ & $23.5(16.3)$ & $2.0 \mathrm{~ns}$ & $0.92(7.6)$ & $0.92(8.3)$ & $0.92(7.9)$ & $0.00 \mathrm{~ns}$ \\
\hline Nongrafted & $47.7(54.7)$ & $71.2(88.1)$ & $59.4(71.4)$ & $23.5 * *$ & $1.51(31.5)$ & $1.72(51.6)$ & $1.61(41.5)$ & $0.21 \mathrm{~ns}$ \\
\hline Mean & $23.5(23.2)$ & $32.9(35.4)$ & $\ldots$ & 9.4 & $0.81(13.0)$ & $0.91(20.1)$ & $\ldots$ & $0.10 \mathrm{~ns}$ \\
\hline $\mathrm{SA}$ & $P=0.0059$ & $\ldots$ & $\ldots$ & $\ldots$ & $P=0.1803$ & $\ldots$ & $\ldots$ & $\ldots$ \\
\hline $\mathrm{P}$ & $P<0.0001$ & $\ldots$ & $\ldots$ & $\ldots$ & $P<0.0001$ & $\ldots$ & $\ldots$ & $\ldots$ \\
\hline $\mathrm{SA} \times \mathrm{P}$ & $P=0.0139$ & $\ldots$ & $\ldots$ & $\ldots$ & $P=0.5471$ & $\ldots$ & $\ldots$ & $\ldots$ \\
\hline LSD & 10.4 & $\ldots$ & $-^{\mathrm{d}}$ & $\ldots$ & 0.29 & $\ldots$ & 0.20 & $\ldots$ \\
\hline \multicolumn{9}{|l|}{ TSS } \\
\hline EG203 & $0.3(0.0)$ & $0.3(0.0)$ & $0.3(0.0)$ & $0.0 \mathrm{~ns}$ & $0.00(0.0)$ & $0.00(0.0)$ & $0.00(0.0)$ & $0.00 \mathrm{~ns}$ \\
\hline Hawaii 7996 & $7.1(2.2)$ & $15.2(7.0)$ & $11.1(4.6)$ & $8.1 *$ & $0.19(0.6)$ & $0.56(2.6)$ & $0.38(1.6)$ & $0.37 *$ \\
\hline Nongrafted & $25.4(19.1)$ & $29.2(24.4)$ & $27.3(21.8)$ & $3.8 \mathrm{~ns}$ & $0.91(8.3)$ & $1.05(11.3)$ & $0.98(9.8)$ & $0.14 \mathrm{~ns}$ \\
\hline Mean & $10.9(7.1)$ & $14.9(10.5)$ & $\ldots$ & $4.0 \mathrm{~ns}$ & $0.37(3.0)$ & $0.53(4.6)$ & $\ldots$ & $0.16 *$ \\
\hline $\mathrm{SA}$ & $P=0.0880$ & $\ldots$ & $\ldots$ & $\ldots$ & $P=0.0414$ & $\ldots$ & $\ldots$ & $\ldots$ \\
\hline $\mathrm{P}$ & $P<0.0001$ & $\ldots$ & $\ldots$ & $\ldots$ & $P<0.0001$ & $\ldots$ & $\ldots$ & $\ldots$ \\
\hline $\mathrm{SA} \times \mathrm{P}$ & $P=0.3240$ & $\ldots$ & $\ldots$ & $\ldots$ & $P=0.1560$ & $\ldots$ & $\ldots$ & $\ldots$ \\
\hline LSD & 8.0 & $\ldots$ & 5.7 & $\ldots$ & 0.28 & $\ldots$ & 0.20 & $\ldots$ \\
\hline
\end{tabular}

${ }^{a}$ Each kind of plant material was grown in plots with (SA) or without (w/o SA) an amending mixture of urea $(825 \mathrm{~kg} / \mathrm{ha})$ and $\mathrm{Ca}(\mathrm{OH})_{2}(3993 \mathrm{~kg} / \mathrm{ha})$. Percentage and RAUDPC data were transformed to arcsine square root and log (RAUDPC +1$)$, respectively, for statistical analyses. Fisher's least significant difference (LSD) based on transformed values was calculated and significant at $P<0.05$ by location; values inside parentheses are actual means.

b Plant materials (P) included seedlings of ASVEG10 (nongrafted) and ASVEG10 grafted onto EG203 (EG203) or Hawaii 7996. WL= Wenlin Chunglin, TC = Tungchuang Kuantien, and TSS = Taiwan Seed Improvement and Propagation Station.

${ }^{\mathrm{c}}$ Effect of SA was tested collectively for each experiment or by plant materials of each experiment; ** and * $=$ significant at $P<0.01$ and 0.05 , respectively, and $\mathrm{ns}=$ nonsignificant.

${ }^{\mathrm{d}}$ Interaction of SA $\times \mathrm{P}$ was significant in the AVRDC experiment and main effect of SA and P could not be compared. 
preliminary screen in WL and AVRDC soils did not result in significant reduction in disease incidence for all types of plant materials in the field. In field experiments, the mean reduction in disease incidences over plant materials was 11.8 and $12.2 \%$ at WL and AVRDC sites, respectively. This suggests that a preliminary screen of pathogen survival in soil at $30^{\circ} \mathrm{C}$ cannot predict the field control efficacy of SA.

Field experiments were conducted at four locations to evaluate the effect of resistant rootstock and SA alone or together. Despite the differences in disease pressure, the ranking of the treatments for their ability to control the disease was stable and similar over the four experiments. The low disease pressure in TSS field experiments could be due to the lower temperature and slower pathogen dissemination, due to the use of trickle irrigation by a perforated plastic soaker hose, compared with the other experiment locations, where furrow irrigation was used. At the TC site, the initial pathogen density was low and the field was kept under low soil moisture compared with the other experiments. Planting resistant material provided greater and more stable disease control at the TC site. Under high disease pressure, disease incidence was effectively reduced by grafting, especially with eggplant rootstock, which provided 90 and $87 \%$ reduction of incidence in the WL and AVRDC experiments, respectively, and increased yield to $33.8 \mathrm{t} / \mathrm{ha}$ in the WL experiment. Thus, planting resistant plant material, either resistant cultivars or resistant rootstocks, should continue to be the main strategy for controlling tomato bacterial wilt.

Resistant rootstock is an immediate solution for controlling tomato bacterial wilt, particularly EG203, which provided stable and high resistance. However, the solanaceous resistant cv. EG203 and line Hawaii 7996 are not immune to $R$. solanacearum $(44,46)$. The resistance provided by rootstocks appears due to the limitation of bacterial spread in the lower part of the stem (10). Thus, continuous monitoring should be performed for new strain types that could overcome the resistance in EG203. During this study period, the cost of a grafted seedling was at least three NT dollars more than a nongrafted one. Thus, grafting with resistant rootstocks is recommended only when the risk of the disease is high and it is cost effective, because the yield increase might not be significant when disease pressure is low, as we observed in this study. During the field experiments, slower early vegetative growth and changes of fruit quality, including smaller size, more blossom end rot, higher soluble solids, and higher citric acid content, were observed when eggplant rootstock was used compared with tomato. However, the effect on fruit quality was not consistent. When using scarlet eggplant (S. integrifolium Poir.) as rootstock for tomato, similar results were observed and attributed to poor connection of vascular bundles at the graft union or a poor root system making the plant water deficient (34). These results highlight the need for screening to identify the scion and rootstock combination with the least detrimental effect on fruit quality as well as the need to develop proper management practices for grafted tomato plants using eggplant rootstocks, such as maintaining higher soil moisture (3).

SA had a significant effect only under moderate disease pressure in the field. SA can decrease initial inoculum density and, thus, delay disease development. Despite the fact that SA treatment has no effect on yield, decreasing pathogen population size can reduce the evolutionary potential of the pathogen (29), which could prolong the longevity of a resistant genotype. Synergistic effect of the two components on disease control as well as yield increase was observed only in the case of integrating Hawaii 7996 rootstock and SA in the WL experiment. This suggests that the use of SA is most beneficial when moderately resistant plant materials and high disease pressure co-exist. Moreover, amending urea and $\mathrm{Ca}(\mathrm{OH})_{2}$ or any kind of SA could have an effect on the soil microbial community and, thus, its effect on the longterm sustainability of a local production system should not be overlooked. Stark et al. (41) reported that organic nitrogenous amendments such as lupin could increase microbial biomass and activity as well as influence microbial community structure within a short term, whereas the urea amendment showed no significant effect. Thus, a worthwhile topic for future research is to look for an organic replacement of chemical amendments in controlling tomato bacterial wilt. It has been shown that liming could increase soil microbial mass in acidic soils despite the degree of tillage and crop sequence (40). Therefore, the benefits of SA application could be multifold.

This study demonstrated good consistency between results of the preliminary screens and field experiments on wilt disease control efficacy of resistant rootstocks, but not that of the SA of urea and $\mathrm{Ca}(\mathrm{OH})_{2}$. Integrating host resistance, such as resistant rootstock, and the SA tested did not show consistent synergistic effect. This indicates the presence of other envi-

Table 5. Effect of resistant rootstock and soil amendment (SA) alone or together on yield and fruit quality of tomato cv. ASVEG10 in field experiments conducted at Chunglin and Kuantien ${ }^{\mathrm{a}}$

\begin{tabular}{|c|c|c|c|c|c|c|c|c|c|c|c|c|}
\hline \multirow[b]{2}{*}{ Site, $\mathbf{P}^{\mathbf{b}}$} & \multicolumn{3}{|c|}{ Yield (t/ha) } & \multicolumn{3}{|c|}{ Fruit weight (g) } & \multicolumn{3}{|c|}{ Soluble solid $\left(\right.$ Brix $\left.^{\circ}\right)$} & \multicolumn{3}{|c|}{ Acidity (\% citric acid) } \\
\hline & SA & w/o SA & Mean & SA & w/o SA & Mean & SA & w/o SA & Mean & SA & w/o SA & Mean \\
\hline \multicolumn{13}{|l|}{ WL } \\
\hline EG203 & 35.7 & 35.8 & 35.8 & 166 & 160 & 163 & 5.20 & 5.37 & 5.28 & 0.44 & 0.44 & 0.44 \\
\hline Hawaii 7996 & 37.2 & 23.3 & 30.3 & 177 & 161 & 169 & 4.90 & 4.80 & 4.86 & 0.38 & 0.40 & 0.39 \\
\hline Nongrafted & 1.8 & 2.0 & 1.9 & na & na & $\ldots$ & na & na & $\ldots$ & na & na & $\ldots$ \\
\hline Mean & 24.9 & 20.4 & $\ldots$ & 172 & 161 & $\ldots$ & 5.05 & 5.14 & $\ldots$ & 0.41 & 0.42 & $\ldots$ \\
\hline SA & $P=0.1201$ & $\ldots$ & $\ldots$ & $P=0.0588$ & $\ldots$ & $\ldots$ & $P=0.5367$ & $\ldots$ & $\ldots$ & $P=0.1813$ & $\ldots$ & $\ldots$ \\
\hline $\mathrm{P}$ & $P<0.0001$ & $\ldots$ & $\ldots$ & $P=0.2120$ & $\ldots$ & $\ldots$ & $P=0.0015$ & $\ldots$ & $\ldots$ & $P=0.0030$ & $\ldots$ & $\ldots$ \\
\hline $\mathrm{SA} \times \mathrm{P}$ & $P=0.0918$ & $\ldots$ & $\ldots$ & $P=0.3094$ & $\ldots$ & $\ldots$ & $P=0.1279$ & $\ldots$ & $\ldots$ & $P=0.4486$ & $\ldots$ & $\ldots$ \\
\hline LSD & 10.3 & $\ldots$ & 7.2 & ns & $\ldots$ & ns & 0.23 & $\ldots$ & 0.16 & 0.03 & $\ldots$ & 0.02 \\
\hline \multicolumn{13}{|l|}{ TC } \\
\hline EG203 & 41.0 & 46.6 & 43.8 & 132 & 127 & 130 & 4.3 & 4.5 & 4.4 & 0.36 & 0.38 & 0.37 \\
\hline Hawaii 7996 & 50.0 & 51.6 & 50.8 & 140 & 150 & 145 & 4.4 & 4.4 & 4.4 & 0.34 & 0.38 & 0.36 \\
\hline Nongrafted & 35.9 & 30.1 & 33.0 & 137 & 125 & 131 & 4.9 & 4.4 & 4.7 & 0.38 & 0.38 & 0.38 \\
\hline Mean & 42.3 & 42.8 & $\ldots$ & 136 & 134 & $\ldots$ & 4.5 & 4.4 & $\ldots$ & 0.36 & 0.38 & $\ldots$ \\
\hline SA & $P=0.9362$ & $\ldots$ & $\ldots$ & $P=0.6907$ & $\ldots$ & $\ldots$ & $P=0.4652$ & $\ldots$ & $\ldots$ & $P=0.0934$ & $\ldots$ & $\ldots$ \\
\hline $\mathrm{P}$ & $P=0.0949$ & $\ldots$ & $\ldots$ & $P=0.0664$ & $\ldots$ & $\ldots$ & $P=0.1982$ & $\ldots$ & $\ldots$ & $P=0.4384$ & $\ldots$ & $\ldots$ \\
\hline $\mathrm{SA} \times \mathrm{P}$ & $P=0.7401$ & $\ldots$ & $\ldots$ & $P=0.2331$ & $\ldots$ & $\ldots$ & $P=0.1224$ & $\ldots$ & $\ldots$ & $P=0.7795$ & $\ldots$ & $\ldots$ \\
\hline LSD & ns & $\ldots$ & $\mathrm{ns}$ & ns & $\ldots$ & ns & ns & $\ldots$ & ns & ns & $\ldots$ & $\mathrm{ns}$ \\
\hline
\end{tabular}

${ }^{a}$ Each plant material (P) was grown in plots with $(\mathrm{SA})$ or without (w/o SA) an amending mixture of urea $(825 \mathrm{~kg} / \mathrm{ha}) \mathrm{and} \mathrm{Ca}(\mathrm{OH})_{2}(3,993 \mathrm{~kg} / \mathrm{ha}) ; \mathrm{na}=\mathrm{not}$ applicable.

b Plant materials included seedlings of ASVEG10 (nongrafted) and ASVEG10 grafted onto EG203 (EG203) or Hawaii 7996. Fisher's least significant difference (LSD) was calculated by location and significant at $P<0.05 . \mathrm{WL}=$ Wenlin Chunglin and TC $=$ Tungchuang Kuantien. 
ronmental factors affecting the control efficacy and, thus, it is necessary to evaluate and develop integrated disease management packages locally for tomato bacterial wilt.

\section{ACKNOWLEDGMENTS}

This article is based on a portion of a Ph.D. dissertation by C.-H. Lin. The research was supported by funds from the Bureau of Animal and Plant Health Inspection and Quarantine, Council of Agriculture of Taiwan [91AS-7.2.3-BQ-B1(3), 92AS-1.8.1-BQ- B4(5), and 93MN-3.2-PP-1(2)]. We thank H.-H. Liau, M.-H. Chuang, J.-Y. Lu, and C.-F. Hsu for their technical assistance; and D. R. Ledesma for helpful statistical analysis.

\section{LITERATURE CITED}

1. Anith, K. N., Momol, M. T., Kloepper, J. W., Marois, J. J., Olson, S. M., and Jones, J. B. 2004. Efficacy of plant growth-promoting rhizobacteria, acibenzolar- $S$-methyl, and soil amendment for integrated management of bacterial wilt on tomato. Plant Dis. 88:669-673.

2. Bertolla, F., Frostegård, Å., Brito, B., Nesme, X., and Simonet, P. 1999. During infection of its host, the plant pathogen Ralstonia solanacearum naturally develops a state of competence and exchanges genetic material. Mol. Plant-Microbe Interact. 12:467-472.

3. Black, L. L., Wu, D.-L., Wang, J.-F., Kalb, T., Abbass, D., and Chen, J.-H. 2003. Grafting tomatoes for production in the hot-wet season. AVRDC International Cooperators' Guide. AVRDC Publ. no. 03-551.

4. Elphinstone, J. G. 2005. The current bacterial wilt situation: a global overview. Pages 9-28 in: Bacterial Wilt Disease and the Ralstonia solanacearum Species Complex. C. Allen, P. Prior., and A. C. Hayward, eds. American Phytopathological Society Press, St. Paul, MN.

5. Elphinstone, J. G., and Aley, P. 1993. Integrated control of bacterial wilt of potato in the warm tropics of Peru. Pages 276-283 in: Bacterial Wilt. ACIAR Proc. 45. G. L. Hartman and A. C. Hayward, eds. Watson Ferguson and Company, Brisbane, Australia.

6. Enfinger, J. M., McCarter, S. M., and Jaworski, C. A. 1979. Evaluation of chemicals and application methods for control of bacterial wilt of tomato transplants. Phytopathology 69:637-640.

7. Engelbrecht, M. C., Van Wyk, R. J., Engelbrecht, S. La G., and Janse Van Rensburg, J. N. 1990. Control of bacterial wilt of tobacco with chloropicrin in South Africa. Phytophylactica 22:269-271.

8. Fry, W. E. 1978. Quantification of general resistance of potato cultivars and fungicide effects for integrated control of potato late blight. Phytopathology 68:1650-1655.

9. Granada, G. A., and Sequeira, L. 1983. A new selective medium for Pseudomonas solanacearum. Plant Dis. 67:1084-1088.

10. Grimault, V., and Prior, P. 1994. Grafting tomato cultivars resistant or susceptible to bacterial wilt: analysis of resistance mechanisms. J. Phytopathol. 141:330-334.

11. Hanson, P. M., Wang, J.-F., Licardo, O., Hanudin, Mah, S. Y., Hartman, G. L., Lin, Y.-C., and Chen, J.-T. 1996. Variable reaction of tomato lines to bacterial wilt evaluated at several locations in Southeast Asia. HortScience 31:143-146.

12. Hanson, P. M., Yang, R.-Y., Wu, J., Chen, J.-T., Ledesma, D., Tsou, S. C. S., and Lee, T.-C. 2004. Variation for antioxidant activity and antioxidants in tomato. J. Am. Soc. Hortic. Sci. 129:704-711.

13. Hartman, G. L., and Elphinstone, J. G. 1994.
Advances in the control of Pseudomonas solanacearum race 1 in major food crops. Pages 157-177 in: Bacterial Wilt: the Disease and its Causative Agent, Pseudomonas solanacearum. A. C. Hayward and G. L. Hartman, eds. CAB International, Wallingford, UK.

14. Hartman, G. L., Hong, W.-F., and Wang, T.-C. 1991. Survey of bacterial wilt on fresh market hybrid tomatoes in Taiwan. Plant Prot. Bull. (Taiwan) 33:197-203

15. Haubold, B., and Rainey, P. B. 1997. Towards an understanding of the population genetics of plant-colonizing bacteria. Adv. Bot. Res. 24:335-351.

16. Hayward, A. C. 2000. Ralstonia solanacearum. Encycl. Microbiol. 4:32-42.

17. Hong, T.-L., and Tsou, S. C. S. 1998. Quality analysis of tomato using near infrared spectroscopy. J. Chin. Agric. Chem. Soc. (Taiwan) 36:418-424. (In Chinese)

18. Hsu, S.-T. 1991. Ecology and control of Pseudomonas solanacearum in Taiwan. Plant Prot. Bull. (Taiwan) 33:72-79.

19. Hsu, S.-T., Tsai, T.-T., and Tzeng, K.-C. 1979. Pathovars of Pseudomonas solanacearum in Taiwan and their interaction in tobacco plants. Natl. Sci. Counc. Mon. (Taipei) 7:609-620. (In Chinese)

20. Ioannou, N. 2001. Integrating soil solarization with grafting on resistant rootstocks for management of soil-borne pathogens of eggplant. J. Hortic. Sci. Biotechnol. 76:396-401.

21. Jaunet, T. X., and Wang, J.-F. 1999. Variation in genotype and aggressiveness of Ralstonia solanacearum race 1 isolated from tomato in Taiwan. Phytopathology 89:320-327.

22. Kado, C. I., and Heskett, M. G.. 1970. Selective media for isolation of Agrobacterium, Corynebacterium, Erwinia, Pseudomonas, and Xanthomonas. Phytopathology 60:969-976.

23. Kay, E., Chabrillat, G., Vogel, T. M., and Simonet, P. 2003. Intergeneric transfer of chromosomal and conjugative plasmid genes between Ralstonia solanacearum and Acinetobacter sp. BD413. Mol. Plant-Microbe Interact. 16:74-82.

24. Kelman, A. 1954. The relationship of pathogenicity in Pseudomonas solanacearum to colony appearance on a tetrazolium medium. Phytopathology 44:693-695.

25. Lee, J.-M. 1994. Cultivation of grafted vegetables I. Current status, grafting methods, and benefits. HortScience 29:235-239.

26. Lin, C.-H., and Wang, J.-F. 2004. Formulating locally effective integrated management packages for tomato bacterial wilt. (Abstr.) Phytopathology 94:S61.

27. Lin, C.-H., Wu, D.-L., Imai, H., and Wang, J.F. 1998. Grafting with resistant tomato and eggplant rootstocks to control tomato bacterial wilt. (Abstr.) Plant Pathol. Bull. (Taiwan) 7:216-217.

28. Lopes, C. A., Quezado-Soares, A. M., and de Melo, P. E. 1994. Differential resistance of tomato cultigens to biovars I and III of Pseudomonas solanacearum. Plant Dis. 78:10911094.

29. McDonald, B. A., and Linde, C. 2002. Pathogen population genetics, evolutionary potential, and durable resistance. Annu. Rev. Phytopathol. 40:349-379.

30. Michel, V. V., and Mew, T. W. 1998. Effect of a soil amendment on the survival of Ralstonia solanacearum in different soils. Phytopathology 88:300-305.

31. Michel, V. V., Tzeng, C.-C., and Wang, J.-F. 1996. Relationship between Pseudomonas solanacearum population in soil and bacterial wilt progress of tomato. ACIAR Bacterial Wilt Newsl. 13:6-7.
32. Michel, V. V., Wang, J.-F., Midmore, D. J., and Hartman, G. L. 1997. Effects of intercropping and soil amendment with urea and calcium oxide on the incidence of bacterial wilt of tomato and survival of soil-borne Pseudomonas solanacearum in Taiwan. Plant Pathol. 46:600610.

33. Milgroom, M. G., and Fry, W. E. 1997. Contributions of population genetics to plant disease epidemiology and management. Adv. Bot. Res. 24:1-30.

34. Oda, M., Nagata, M., Tsuji, K., and Sasaki, H. 1996. Effects of scarlet eggplant rootstock on growth, yield, and sugar content of grafted tomato fruits. J. Jpn. Soc. Hortic. Sci. 65:531536.

35. Peregrine, W. T. H., and Ahmad, K. B. 1982. Grafting - a simple technique for overcoming bacterial wilt in tomato. Trop. Pest Manage. 28:71-76.

36. Prior, P., Steva, H., and Cadet, P. 1990. Aggressiveness of strains of Pseudomonas solanacearum from the French West Indies (Martinique and Guadeloupe) on tomato. Plant Dis. 74:962-965.

37. Scott, J. W., Wang, J.-F., and Hanson, P. M. 2005. Breeding tomatoes for resistance to bacterial wilt, a global view. Acta Hortic. 695:161172.

38. Smiley, R. W., and Cook, R. J. 1972. Use and abuse of the soil $\mathrm{pH}$ measurement. Phytopathology 62:193-194.

39. Smith, T. E., and Clayton, E. E. 1943. Control of Granville wilt (Bacterium solanacearum) of tobacco and other plants by applications of urea to the soil. Phytopathology 33:11-12.

40. Soon, Y. K., and Arshad, M. A. 2005. Tillage and liming effects on crop and labile soil nitrogen in an acid soil. Soil Till. Res. 80:23-33.

41. Stark, C., Condron, L. M., Stewart, A., Di, H J., and O'Callaghan, M. 2007. Influence of organic and mineral amendments on microbial soil properties and processes. Appl. Soil Ecol. 35:79-93.

42. Tremblay, N., Bélec, C., Coulombe, J., and Godin, C. 2005. Evaluation of calcium cyanamide and liming for control of clubroot disease in cauliflower. Crop Prot. 24:798-803.

43. Tsai, J.-W., Hsu, S.-T., and Chen, L.-C. 1985. Bacteriocin-producing strains of Pseudomonas solanacearum and their effect on development of bacterial wilt of tomato. Plant Prot. Bull. (Taiwan) 27:267-278.

44. Wang, J.-F., Chen, N.-C., and Li, H.-M. 1998. Resistance sources to bacterial wilt in eggplant (Solanum melongena). Pages 284-289. in: Bacterial Wilt Disease: Molecular and Ecological Aspects. P. Prior, C. Allen, and J. Elphinstone, eds. Springer-Verlag, Berlin.

45. Wang, J.-F., Hanson, P., and Barnes, J. A. 1998. Worldwide evaluation of an international set of resistance sources to bacterial wilt in tomato. Pages 269-275 in: Bacterial Wilt Disease: Molecular and Ecological Aspects. P Prior, C. Allen, and J. Elphinstone, eds. Springer-Verlag, Berlin.

46. Wang, J.-F., and Lin, C.-H. 2005. Colonization capacity of Ralstonia solanacearum tomato strains differing in aggressiveness on tomatoes and weeds. Pages 73-79. in: Bacterial Wilt Disease and the Ralstonia solanacearum Species Complex. C. Allen, P. Prior, and A. C. Hayward, eds. American Phytopathological Society Press, St. Paul, MN.

47. Wang, J.-F., Lin, C.-H., Wu, D.-L., Cheng, A.H., Wang, S.-S., Black, L. L., and Yen, J.-H. 1999. Management of major soil-borne diseases of cherry tomato by grafting onto eggplant rootstock. (Abstr.) Plant Pathol. Bull. (Taiwan) 8:173. 